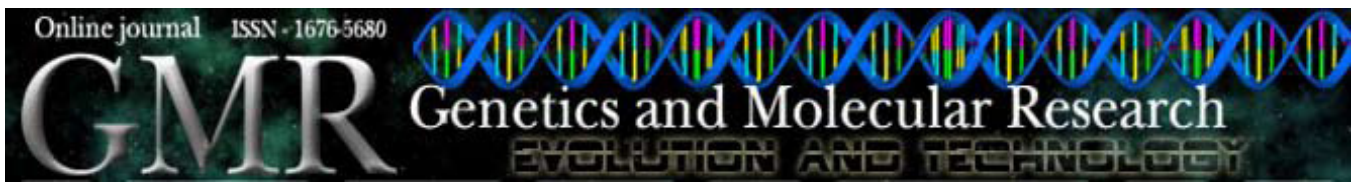

\title{
Behavior and viability of spontaneous oxidative stress-resistant Lactococcus lactis mutants in experimental fermented milk processing
}

\author{
M.N. Oliveira ${ }^{1}$, K.E. Almeida ${ }^{1}$, M.R. Damin ${ }^{1}$, T. Rochat ${ }^{2}$, \\ J.-J. Gratadoux ${ }^{2}$, A. Miyoshi ${ }^{3}$, P. Langella ${ }^{2}$ and V. Azevedo ${ }^{3}$ \\ ${ }^{1}$ Departamento de Tecnologia Farmacêutica e Bioquímica, \\ Universidade de São Paulo, São Paulo, SP, Brasil \\ ${ }^{2}$ Unité d'Ecologie et Physiologie du Système Digestif, \\ Institut National de la Recherche Agronomique, Domaine de Vilvert, France \\ ${ }^{3}$ Instituto de Ciências Biológicas, \\ Universidade Federal de Minas Gerais, Belo Horizonte, MG, Brasil \\ Corresponding author: M.N. Oliveira \\ E-mail: monolive@usp.br
}

Genet. Mol. Res. 8 (3): 840-847 (2009)

Received May 11, 2009

Accepted May 14, 2009

Published July 21, 2009

\begin{abstract}
Previously, we isolated two strains of spontaneous oxidative ( $\mathrm{SpOx} 2$ and $\mathrm{SpOx} 3$ ) stress mutants of Lactococcus lactis subsp cremoris. Herein, we compared these mutants to a parental wild-type strain (J60011) and a commercial starter in experimental fermented milk production. Total solid contents of milk and fermentation temperature both affected the acidification profile of the spontaneous oxidative stress-resistant L. lactis mutants during fermented milk production. Fermentation times to $\mathrm{pH} 4.7$ ranged from $6.40 \mathrm{~h}$ (J60011) to $9.36 \mathrm{~h}(\mathrm{SpOx} 2) ; \mathrm{V}_{\max }$ values were inversely proportional to fermentation time. Bacterial counts increased to above $8.50 \log _{10}$ $\mathrm{cfu} / \mathrm{mL}$. The counts of viable $\mathrm{SpOx} 3$ mutants were higher than those
\end{abstract}


of the parental wild strain in all treatments. All fermented milk products showed post-fermentation acidification after $24 \mathrm{~h}$ of storage at $4^{\circ} \mathrm{C}$; they remained stable after one week of storage.

Key words: Lactococcus lactis; Acidification kinetics; Oxidative stress; Spontaneous mutants

\section{INTRODUCTION}

Lactococcus lactis is a mesophilic (optimal growth temperature around $30^{\circ} \mathrm{C}$ ) and microaerophilic fermenting lactic acid bacteria, widely used in the dairy industry for the production of cheeses and fermented milk products (Duwat et al., 2000). During industrial processes, L. lactis can be exposed to low and high temperature and $\mathrm{pH}$, high osmotic pressure, nutrient starvation, and oxygen, resulting in stress that can affect viability and reproducibility. Among these stress factors, oxidation can be considered one of the most deleterious to bacteria, causing cellular damage at both the molecular and metabolic level, spontaneous mutation, and bacteriostatic and bactericidal effects (Berlett and Stadtman, 1997; Fridowich, 1998; Miyoshi et al., 2003). The kinetics of acidification of the stressed bacteria can be affected, as well as sensory properties of the fermented product (Damin et al., 2008).

The main characteristic of L. lactis is acid production; growth and acidification can be monitored by measuring lactic acid production or $\mathrm{pH}$ (Walstra et al., 2006). $\mathrm{pH}$ can be measured during productions, which is very advantageous for monitoring and controlling the acidification process (Tamime et al., 2001; Almeida et al., 2008). Quantifying the acidifying activity of lactic acid bacteria allows the comparison of different combinations of starters in several substrates in order to define the better trial.

Rochat et al. (2005) developed a strategy to isolate oxidative stress-resistant L. lactis MG1363 derivatives. They evaluated the resistance of spontaneous oxidative stress ( $\mathrm{SpOx}$ ) mutants against other oxidative stresses, acidic conditions and bile salts. Initially, it was found that three SpOx mutants selected on $\mathrm{H}_{2} \mathrm{O}_{2}$ were not resistant to other stress conditions. However, two SpOx mutants (SpOx2 and $\mathrm{SpOx} 3$ ) were more resistant to such conditions, after exposure to $\mathrm{H}_{2} \mathrm{O}_{2}$, than was the parental dairy strain. In the present paper, we examined the behavior of these strains during milk fermentation, investigating the effects of milk total solid contents and fermentation temperature on the kinetics of acidification parameters, viability and post-acidification development of fermented milk.

\section{MATERIAL AND METHODS}

\section{Strains and starter culture}

We used three strains of L. lactis subsp cremoris (J60011, SpOx2 and SpOx3) from the Unité de Recherches Laitières et de Génétique Appliquée, Institut National de la Recherche Agronomique - UR-LGA, INRA (Jouy-en-Josa, France) collection. Dairy-derived strains of L. lactis MG1363 (lac+ and prot+) assigned J60011, constructed by conjugation, were used as controls. Two robust SpOx L. lactis mutants (SpOx2 and SpOx3) were chosen (Rochat et al., 2005). Bacteria were stored at $-40^{\circ} \mathrm{C}$ in M17 medium (Oxoid, Basingstoke, 
England) with $0.5 \%$ lactose added. When required, they were grown overnight at $30^{\circ} \mathrm{C}$ in whole milk that had been sterilized at $121^{\circ} \mathrm{C}$ for $10 \mathrm{~min}$, and the culture was used immediately to inoculate milk.

A commercial starter culture (MA016, Rodhia Food, ZA des Engenières, France) containing L. lactis subsp lactis and L. lactis subsp cremoris was used for comparison with the mutant strains. Spray-dried inocula (10 mg) were diluted in $50 \mathrm{~mL}$ sterilized skim milk reconstituted at $9 \%$ of total solids 5 min before use.

\section{Comparative behavior of SpOx mutants during milk fermentation}

Pasteurized milk Top Paulista B type (Paulista, São Paulo, Brazil), which contained 12.2 $\pm 0.0 \mathrm{~g} / 100 \mathrm{~g}$ of total solids (TS), was used. Skim milk powder was added to obtain $15 \%$ TS (Gloria, Itaperuna, Brazil). After analysis, this milk was found to contain $14.9 \pm 0.3 \mathrm{~g} / 100 \mathrm{~g}$ TS.

Subsequently, the milk (either $12 \%$ TS or $15 \%$ TS) was poured into 250 -mL flasks, which had been sterilized at $121^{\circ} \mathrm{C}$ for $15 \mathrm{~min}$ and stored for $24 \mathrm{~h}$ at $4^{\circ} \mathrm{C}$ before use. The flasks were warmed and inoculated at the fermentation temperature of $30^{\circ}$ or $35^{\circ} \mathrm{C}$ with 0.25 per 100 $\mathrm{mL}$ of the commercial starter, J60011 (control), SpOx2, or SpOx3 inoculum.

After inoculation, the milk was mixed with a magnetic stirrer (Fisatom, São Paulo, Brazil) in a water-bath for 5 min until stabilization of temperature at $30^{\circ}$ or $35^{\circ} \mathrm{C}$, and connected to a CINAC system equipment (Ysebaert, Frépillon, France) (Corrieu et al., 1988), which allows continuous recording of the $\mathrm{pH}$ and computes the acidification rate during the incubation period. The kinetics of acidification was followed until $\mathrm{pH} 4.7$ was reached, which corresponded to the final fermentation time. Four kinetic parameters were considered: a) $V_{\max }$ (maximum acidification rate, measured in $\mathrm{pH}$ units per $\min (\mathrm{UpH} / \mathrm{min})$; b) $\mathrm{t}_{\mathrm{Vmax}}$ (time to reach the maximum acidification rate), c) $\mathrm{pH}$ corresponding to $\mathrm{V}_{\max }$, and d) $\mathrm{t}_{\mathrm{pH} 4.7}$ (time in $\mathrm{h}$ to reach $\mathrm{pH}$ 4.7). Cooling the product in an ice bath interrupted the fermentation when $\mathrm{pH} 4.7$ was reached. The product was then manually stirred with a stainless steel perforated disk with up and down movements for $\sim 2 \mathrm{~min}$, followed by dispensing the product into $100-\mathrm{mL}$ cups. These cups were heat-sealed using a thermal sealing machine (Selopar, BrasHolanda, Pinhais, Brazil). All fermented milk samples were stored at $4^{\circ} \mathrm{C}$ for one week.

\section{Experimental design and statistical analyses}

The trials were conducted according to a factorial design with two variables (total solid content of milk and fermentation temperature) and two levels for each variable: (T1) milk $12 \%$ $\mathrm{TS} / 30^{\circ} \mathrm{C}$; (T2) milk $12 \% \mathrm{TS} / 35^{\circ} \mathrm{C}$; (T3) milk $15 \% \mathrm{TS} / 30^{\circ} \mathrm{C}$, and (T4) milk $15 \% \mathrm{TS} / 35^{\circ} \mathrm{C}$. A total of four batches were run per bacterial strain, each carried out in two replicates. Results were examined by analysis of variance (ANOVA) using Statistica 6.0, Statsoft (Tulsa, USA). Mean values were compared using the Tukey test, with significance set at $\mathrm{P}<0.05$.

\section{Counts of viable cells and post-fermentation acidification}

Microbiological analysis of the fermented milk was performed after $24 \mathrm{~h}$ (d1) and seven days $(\mathrm{d} 7)$ of storage of the products at $4^{\circ} \mathrm{C}$. Samples $(1.0 \mathrm{~mL})$ were added to $9.0 \mathrm{~mL}$ sterile tryptone diluent $(0.1 \%, \mathrm{w} / \mathrm{v})$; appropriate dilutions were made, and subsequently, plated 
onto M17 medium (Oxoid, Basingstoke, England) supplemented with $0.5 \%$ lactose, and incubated at $30^{\circ} \mathrm{C}$ for $48 \mathrm{~h}$.

Post-fermentation acidification was determined by $\mathrm{pH}$ measurements at $\mathrm{d} 1$ and $\mathrm{d} 7 \mathrm{us}$ ing a pH meter (Quimis model Q-400M1, São Paulo, Brazil).

\section{RESULTS AND DISCUSSION}

\section{Behavior of SpOx mutants during the fermentation process}

Using commercial culture, it was observed that $\mathrm{V}_{\max } \mathrm{T} 1<\mathrm{V}_{\max } \mathrm{T} 2=\mathrm{V}_{\max } \mathrm{T} 4<\mathrm{V}_{\max }$ $\mathrm{T} 3$ (P $\leq$ 0.05; Table 1). Fermented milk prepared with $\mathrm{J} 60011$ resulted in a $\mathrm{V}_{\max }$ that was significantly lower in $\mathrm{T} 1$ than in the other treatments. In $\mathrm{T} 2\left(12 \% \mathrm{TS}\right.$ and $\left.35^{\circ} \mathrm{C}\right), \mathrm{V}_{\max }$ was the highest observed. Lower values of $\mathrm{V}_{\max }$ were observed with $\mathrm{SpOx} 2$, irrespective of treatment, especially at $\mathrm{T} 4$. However, with $\mathrm{SpOx} 3, \mathrm{~V}_{\max }$ varied significantly $(\mathrm{P} \leq 0.05$; Table 1). The effect of total solid contents of milk and temperature on $\mathrm{V}_{\max }$ was straindependent. $\mathrm{V}_{\max }$ increased with total solid content and temperature in commercial, J60011 and $\mathrm{SpOx} 3$ cultures. The maximum acidification rate of $\mathrm{SpOx} 2$ decreased with increasing temperature in $15 \%$ TS milk. Since the variations in the acidification activity of different strains are related to their specific ability to assimilate the nutritive compounds in the medium (Badis et al., 2004), this fact could explain the behavior of SpOx2 under the conditions studied.

\begin{tabular}{|c|c|c|c|c|c|c|c|c|c|}
\hline \multirow[t]{2}{*}{ Treatment } & \multirow[t]{2}{*}{ Culture } & \multirow[t]{2}{*}{$\begin{array}{l}\text { TS } \\
(\%)\end{array}$} & \multirow[t]{2}{*}{$\begin{array}{c}\text { Temperature } \\
\left({ }^{\circ} \mathrm{C}\right)\end{array}$} & \multirow[t]{2}{*}{$\begin{array}{c}\mathrm{V}_{\max } \\
(\mathrm{UpH} / \mathrm{min})\end{array}$} & \multirow[t]{2}{*}{$\begin{array}{l}\mathrm{pH} \text { corresponding } \\
\text { to } \mathrm{V}_{\max }\end{array}$} & \multicolumn{2}{|c|}{$\begin{array}{c}\text { Counts } \\
\left(\log _{10} \mathrm{cfu} / \mathrm{mL}\right)\end{array}$} & \multicolumn{2}{|c|}{$\begin{array}{l}\text { Post-fermentation } \\
\text { acidification }\end{array}$} \\
\hline & & & & & & d1 & d7 & d1 & d7 \\
\hline T1 & Com & 12 & 30 & $9.27^{\text {abcd }}$ & $5.44^{\mathrm{ab}}$ & $9.35^{\text {efg }}$ & $9.75^{\mathrm{hi}}$ & $4.49^{\mathrm{ab}}$ & $4.46^{\mathrm{ab}}$ \\
\hline $\mathrm{T} 2$ & Com & 12 & 35 & $10.40^{\text {efg }}$ & $5.83^{\mathrm{d}}$ & $8.93^{\text {bcd }}$ & $9.10^{\text {cdefg }}$ & $4.48^{\mathrm{a}}$ & $4.44^{\mathrm{a}}$ \\
\hline T3 & Com & 15 & 30 & $10.54^{\mathrm{fg}}$ & $5.5^{\mathrm{bc}}$ & $9.59^{\mathrm{g}}$ & $9.48^{\mathrm{gh}}$ & $4.55^{\text {cd }}$ & $4.54^{\mathrm{cdc}}$ \\
\hline T4 & Com & 15 & 35 & $10.49^{\text {efg }}$ & $5.84^{\mathrm{d}}$ & $9.25^{\text {def }}$ & $8.64^{\mathrm{a}}$ & $4.52^{\mathrm{bc}}$ & $4.50^{\mathrm{bc}}$ \\
\hline T1 & J60011 & 12 & 30 & $8.96^{\mathrm{abc}}$ & $5.38^{\mathrm{ab}}$ & $9.19^{\text {cde }}$ & $9.09^{\text {bcdef }}$ & $4.48^{\mathrm{a}}$ & $4.44^{\mathrm{a}}$ \\
\hline T2 & $\mathrm{J} 60011$ & 12 & 35 & $11.82^{\mathrm{h}}$ & $5.77^{\mathrm{d}}$ & $8.57^{\mathrm{a}}$ & $8.61^{\mathrm{a}}$ & $4.48^{\mathrm{a}}$ & $4.44^{\mathrm{a}}$ \\
\hline T3 & $\mathrm{J} 60011$ & 15 & 30 & $10.07^{\text {defg }}$ & $5.39^{\mathrm{ab}}$ & $9.40^{\text {efg }}$ & $9.23^{\mathrm{efg}}$ & $4.56^{\mathrm{cd}}$ & $4.52^{\text {cd }}$ \\
\hline T4 & J60011 & 15 & 35 & $10.41^{\mathrm{efg}}$ & $5.84^{\mathrm{d}}$ & $8.64^{\mathrm{ab}}$ & $8.73^{\mathrm{abc}}$ & $4.57^{\mathrm{d}}$ & $4.52^{\text {cd }}$ \\
\hline T1 & SpOx2 & 12 & 30 & $8.81^{\mathrm{ab}}$ & $5.35^{\mathrm{a}}$ & $9.55^{\text {fg }}$ & $9.45^{\text {fgh }}$ & $4.48^{\mathrm{a}}$ & $4.46^{\mathrm{a}}$ \\
\hline T2 & SpOx2 & 12 & 35 & $9.55^{\text {bddef }}$ & $5.70^{\mathrm{cd}}$ & $8.92^{\mathrm{bc}}$ & $9.04^{\text {bcde }}$ & $4.51^{\mathrm{ab}}$ & $4.47^{\mathrm{ab}}$ \\
\hline T3 & SpOx2 & 15 & 30 & $9.83^{\text {cdef }}$ & $5.45^{\mathrm{ab}}$ & $9.57^{\mathrm{fg}}$ & $8.71^{\mathrm{ab}}$ & $4.56^{\mathrm{cd}}$ & $4.56^{\mathrm{e}}$ \\
\hline T4 & SpOx2 & 15 & 35 & $8.29^{\mathrm{a}}$ & $5.80^{\mathrm{d}}$ & $9.38^{\mathrm{efg}}$ & $9.17^{\operatorname{defg}}$ & $4.63^{\mathrm{e}}$ & $4.63^{\mathrm{f}}$ \\
\hline T1 & $\mathrm{SpOx} 3$ & 12 & 30 & $8.63^{\mathrm{ab}}$ & $5.35^{\mathrm{a}}$ & $9.31^{\text {efg }}$ & $9.03^{\text {bcde }}$ & $4.50^{\mathrm{ab}}$ & $4.47^{\mathrm{ab}}$ \\
\hline T2 & SpOx3 & 12 & 35 & $10.45^{\text {efg }}$ & $5.71^{\text {cd }}$ & $9.40^{\text {efg }}$ & $9.91^{\mathrm{i}}$ & $4.48^{\mathrm{a}}$ & $4.45^{\mathrm{a}}$ \\
\hline T3 & SpOx3 & 15 & 30 & $9.51^{\text {bcd }}$ & $5.53^{\mathrm{abc}}$ & $9.58^{\mathrm{fg}}$ & $9.62^{\mathrm{hi}}$ & $4.56^{\mathrm{cd}}$ & $4.55^{\mathrm{de}}$ \\
\hline T4 & SpOx3 & 15 & 35 & $10.94^{\mathrm{gh}}$ & $5.76^{\mathrm{d}}$ & $9.17^{\text {de }}$ & $8.83^{\text {abcd }}$ & $4.57^{\mathrm{d}}$ & $4.53^{\text {cde }}$ \\
\hline
\end{tabular}

Different superscript letters in the same column indicate significant differences. Tukey test, $\alpha=0.05$. $\mathrm{V}_{\max }=$ maximum acidification rate (measured in $\mathrm{pH}$ units per min); $\mathrm{d} 1, \mathrm{~d} 7$ : fermented milk stored at $4^{\circ} \mathrm{C}$ for $24 \mathrm{~h}$ and seven days, respectively. 
The time to reach $\mathrm{V}_{\max }\left(\mathrm{t}_{\mathrm{V} \max }\right.$ ) varied significantly, ranging from 3.03 to $6.57 \mathrm{~h}$ (Figure 1). The effect of temperature and total solid content was observed with all cultures. The lowest values of $\mathrm{t}_{\mathrm{V} \max }$ were obtained with the higher temperature and total solid content. When the commercial culture was used, $\mathrm{t}_{\mathrm{V} \max }$ at $35^{\circ} \mathrm{C}$ was $3.01 \mathrm{~h}$ on average, and at $30^{\circ} \mathrm{C}, \mathrm{t}_{\mathrm{V} \max }$ was 5.93 $\mathrm{h}$ on average, almost doubling. The same behavior was observed when J60011, SpOx2 and SpOx3 were employed, but with minor differences between the treatments. Nevertheless, a higher $\mathrm{t}_{\mathrm{Vmax}}$ was obtained with SpOx2 in $\mathrm{T} 1(6.57 \mathrm{~h})$. In all cases, the L. lactis cultures reached $\mathrm{V}_{\text {max }}$ in less time at $35^{\circ} \mathrm{C}$ than at $30^{\circ} \mathrm{C}$.
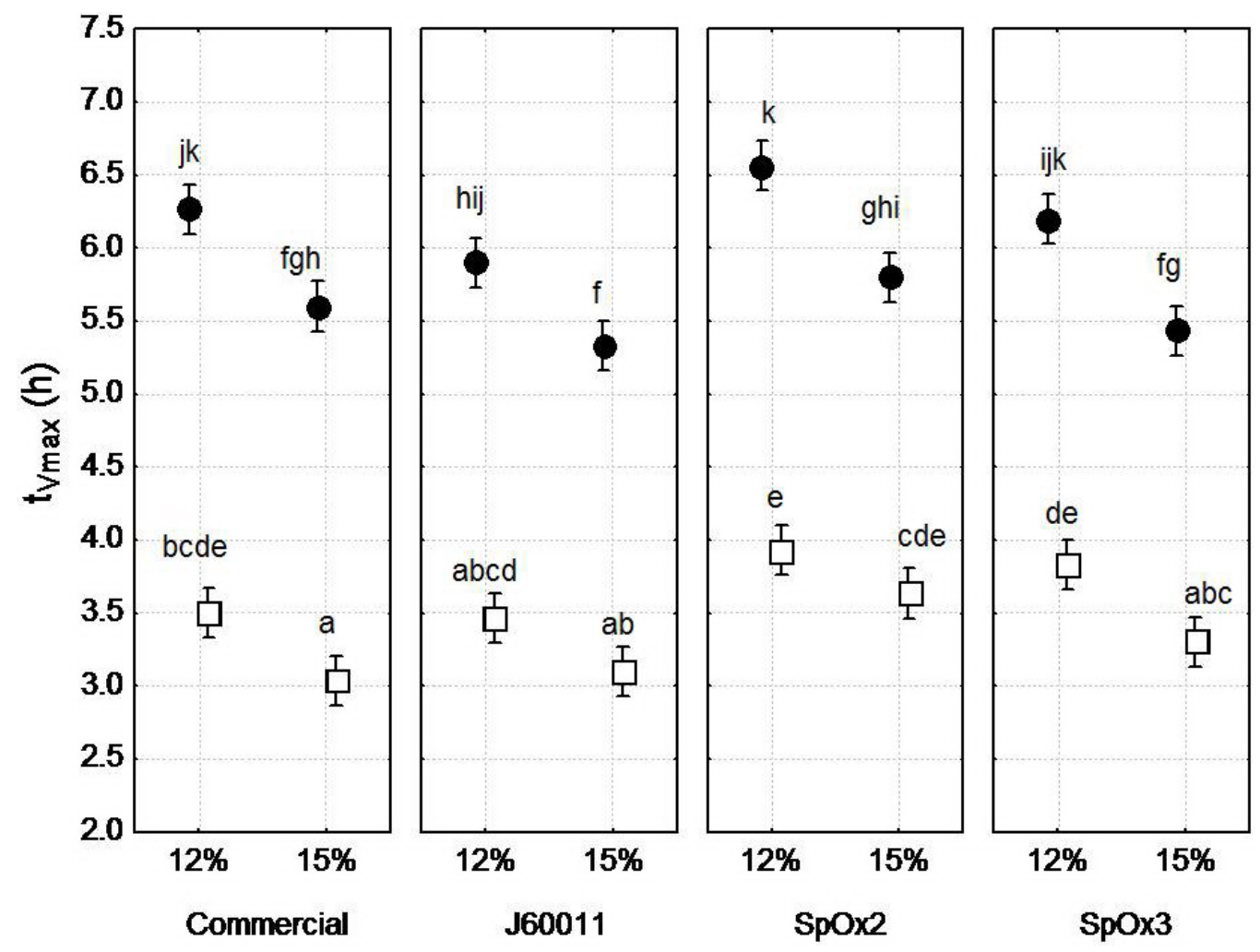

Figure 1. Effect of total solid contents of milk (12 and $15 \%)$ and fermentation temperature $\left(30^{\circ}\right.$ and $\left.35^{\circ} \mathrm{C}\right)$ on time to reach $\mathrm{V}_{\max }\left(\mathrm{t}_{\mathrm{V} \max }\right)$ of milk fermented to $\mathrm{pH} 4.7$ by commercial, J60011 (control), SpOx2 and SpOx3 (mutants) cultures of Lactococcus lactis. Strains were added at $1 \%$ (circles, $30^{\circ} \mathrm{C}$ and squares, $35^{\circ} \mathrm{C}$ ). Values with different letters are significantly different $(\mathrm{P}<0.05)$.

Temperature also influenced the $\mathrm{pH}$ at which $\mathrm{V}_{\max }$ was reached (Table 1). The $\mathrm{pH}$ corresponding to $\mathrm{V}_{\max }$ ranged from 5.35 (SpOx2 in T1) in 5.84 (commercial and $\mathrm{J} 60011$ in T4). When fermentations were carried out at $35^{\circ} \mathrm{C}, \mathrm{pH}$ at $\mathrm{V}_{\max }$ increased to $\sim 5.80$. At the higher temperature, $\mathrm{V}_{\max }$ was reached at higher $\mathrm{pH}$ values, which means that an increase in $5^{\circ} \mathrm{C}$ allowed favorable conditions that the acidification rates of the L. lactis strains studied could be reached in shorter times at $30^{\circ} \mathrm{C}$ (Table 1). According to Kristo et al. (2003), lower total solid 
contents mean lower buffering capacity, which in turn mean a greater decrease in $\mathrm{pH}$ for the same amount of acid produced and vice versa.

The time to reach $\mathrm{pH} 4.7$ varied significantly, from $6.40 \mathrm{~h}(\mathrm{~J} 60011$ in T2) to $9.36 \mathrm{~h}$ ( $\mathrm{SpOx} 2$ in T4) in fermented milk batches (Figure 2). The commercial strain reached pH 4.7 in $\sim 8.65 \mathrm{~h}$ at $30^{\circ} \mathrm{C}$, while at $35^{\circ} \mathrm{C}$, the time decreased to $7.44 \mathrm{~h}$. The culture J60011 was faster than the commercial culture in all treatments (Figure 2), especially in T2, when the difference was significant. This treatment gave the highest $\mathrm{V}_{\max }$ (Table 1), which affected fermentation time.
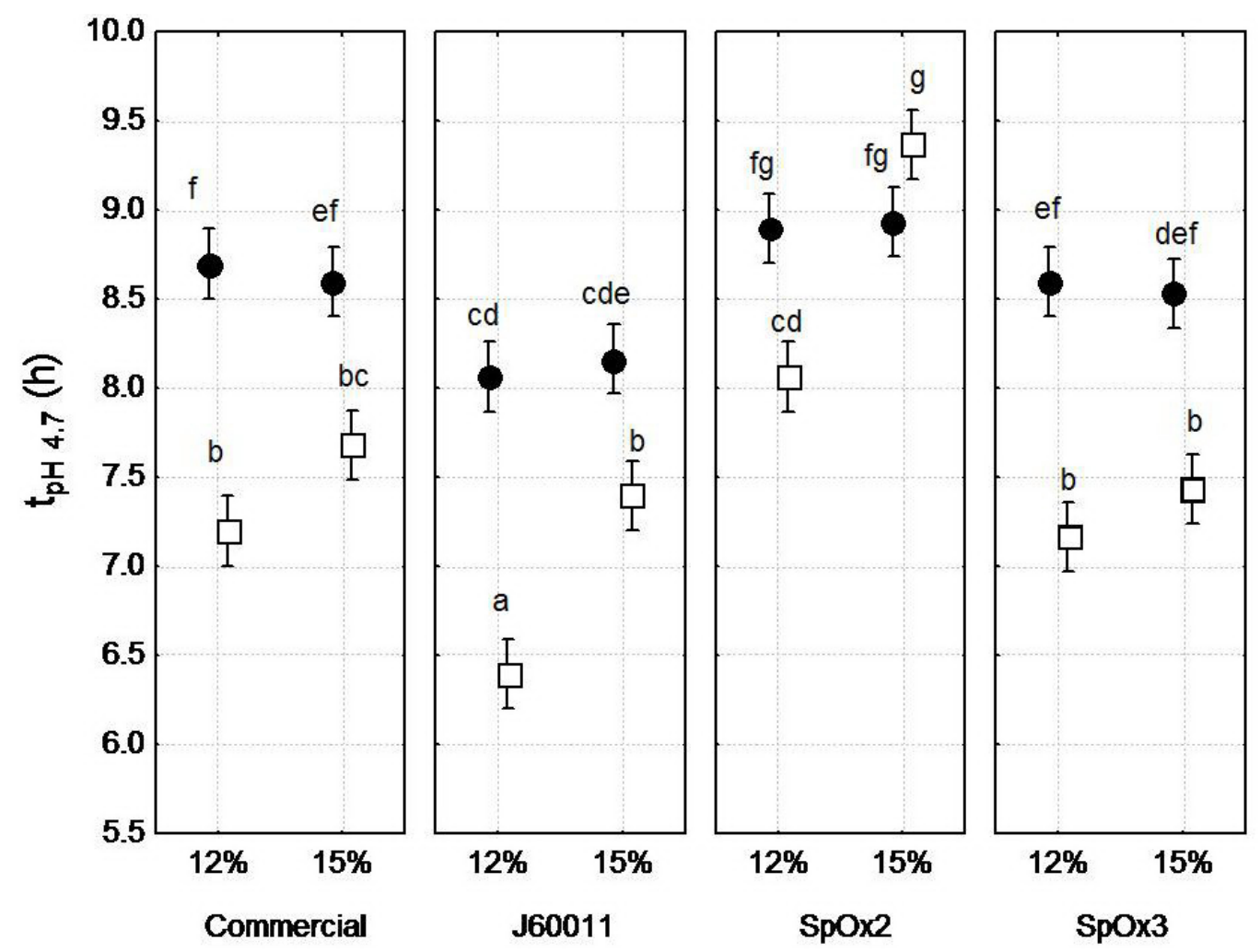

Figure 2. Effect of total solid contents of milk (12 and $15 \%)$ and fermentation temperature $\left(30^{\circ}\right.$ and $\left.35^{\circ} \mathrm{C}\right)$ on fermentation time $\left(\mathrm{t}_{\mathrm{pH} 4.7}\right)$ of milk fermented to $\mathrm{pH} 4.7$ by commercial, J60011 (control), SpOx2 and SpOx3 (mutants) cultures of Lactococcus lactis. Strains were added at $1 \%$ (circles, $30^{\circ} \mathrm{C}$ and squares, $35^{\circ} \mathrm{C}$ ). Values with different letters are significantly different $(\mathrm{P}<0.05)$.

The SpOx 2 culture gave the longest fermentation times, irrespective of treatment. Unlike with the other strains, fermentation time at $35^{\circ} \mathrm{C}$ and $15 \% \mathrm{TS}$ (T4) was longest $(9.36 \mathrm{~h}$ ), which gave the lowest $\mathrm{V}_{\max }\left(8.29 \times 10^{-3} \mathrm{UpH} / \mathrm{min}\right.$, Table 1). However, in general, SpOx2 also showed lower $\mathrm{V}_{\max }$ when compared to the other strains studied, which could characterize it as a bacterial strain with low-acidifying activity.

With SpOx3, fermentation times at $30^{\circ} \mathrm{C}$ were $\sim 8.57 \mathrm{~h}$, while with the temperature increased to $35^{\circ} \mathrm{C}, \mathrm{t}_{\mathrm{pH} 4.7}$ was $\sim 7.25 \mathrm{~h}$. Figure 2 shows that all cultures gave shorter fermentation times at $35^{\circ} \mathrm{C}$ except for $\mathrm{SpOx} 2$ at $15 \% \mathrm{TS}(\mathrm{P} \leq 0.05)$. 
The behavior of $\mathrm{SpOx}$ mutants during milk fermentation varied with percentage of milk solids and temperature and was strain-dependent. Adamberg et al. (2003) observed that when temperature was increased from 25 to $38^{\circ} \mathrm{C}$, the specific growth rate and the specific lactate production rate of $L$. lactis also increased. Similar observations were made when L. lactis ATCC19435 was grown in whole wheat flour from temperatures of 30 to $40^{\circ} \mathrm{C}$. Lactic acid production was optimal between 33 and $35^{\circ} \mathrm{C}$, while D-lactic acid and by-product formation increased at temperatures above $30^{\circ} \mathrm{C}$ (Akerberg et al., 1998). SpOx mutants showed higher acidifying capacity at $30^{\circ} \mathrm{C}$ than $\operatorname{did}$ L. lactis ATCC 19257 at the same temperature, as reported by Grattepanche et al. (2007).

\section{Counts of viable SpOx mutants in fermented milk}

Bacterial counts were done after one and seven days of storage of the fermented milk products at $4^{\circ} \mathrm{C}$. The L. lactis counts $24 \mathrm{~h}$ after the end of fermentation (d1), varied from 8.57 $\log _{10}$ to $9.59 \log _{10} \mathrm{cfu} / \mathrm{mL}$. Commercial, J60011 and SpOx2 counts in T2 were lower than in other treatments, while $\mathrm{T} 3$ (at $15 \%$ and $30^{\circ} \mathrm{C}$ ) gave the highest counts. There was no significant difference in SpOx 3 counts in T1, T2 and T3. However, at 15\% TS, the increase in fermentation temperature resulted in lower counts of $\mathrm{SpOx} 3(\mathrm{P} \leq 0.05)$. The counts of $\mathrm{SpOx} 3$ was higher than that of J60011 in all treatments at d1, confirming the results obtained by Rochat et al. (2005).

After seven days in storage, bacterial counts ranged from $8.64 \log _{10}$ (commercial in T4) to $9.91 \log _{10} \mathrm{cfu} / \mathrm{mL}\left(\mathrm{SpOx} 3\right.$ in T2). Commercial and J60011 counts were higher at $30^{\circ} \mathrm{C}$. SpOx2 and $\mathrm{SpOx} 3$ did not have the same behavior and $\mathrm{SpOx} 3$ gave the highest counts (Table 1).

Our results are similar to those obtained by Gadaga et al. (2001), who studied L. lactis in single culture; they found that viability was reduced during storage of fermented milk. In our study, in general, bacterial counts were higher for all cultures at $35^{\circ} \mathrm{C}$.

\section{Post-fermentation acidification}

All samples showed post-fermentation acidification after $24 \mathrm{~h}$ of storage at $4^{\circ} \mathrm{C}$ (Table 1). On average, using commercial, J60011, $\mathrm{SpOx} 2$ and $\mathrm{SpOx} 3$ cultures, $\mathrm{pH}$ decreased at $\mathrm{d} 1$ $0.19,0.18,0.15$, and $0.17 \mathrm{pH}$ units, respectively. Fermented milk prepared with commercial culture showed a $\mathrm{pH}$ at $\mathrm{d} 1$ ranging from 4.48 to 4.55 , with significant differences mainly in $\mathrm{T} 2$ and T3. After seven days of storage, a similar situation was observed, i.e., the largest differences were observed in T2 and T3. At d1 and d7, using J60011, SpOx2 and SpOx3 cultures in $\mathrm{T} 1$ and $\mathrm{T} 2$, there were no significant differences in $\mathrm{pH}$. Values were higher with milk with $15 \%$ solids. The lowest degree of post-fermentation acidification was observed with the SpOx2 culture in $\mathrm{T} 4$ ( $0.07 \mathrm{pH}$ units). The $\mathrm{pH}$ values of the fermented milk remained stable during one week of storage in all treatments (Table 1).

\section{CONCLUSIONS}

Total milk solids and fermentation temperature both affected the acidification profile of spontaneous oxidative stress resistant $L$. lactis mutants in fermenting milk. Fermentation times ranged from $6.40 \mathrm{~h}$ (J60011) to $9.36 \mathrm{~h}$ (SpOx2), while $\mathrm{V}_{\max }$ values were inversely proportional to fermentation time. Counts surpassed $8.50 \log _{10} \mathrm{cfu} / \mathrm{mL}$. The counts of viable SpOx3 
were higher than those of J60011 in all treatments. All fermented milk products showed postacidification after $24 \mathrm{~h}$ of storage at $4^{\circ} \mathrm{C}$, and remained stable for another six days.

Thus, we suggest that along with their resistance to oxidative stress, SpOx3 mutant shows characteristics that allow it to be used as a starter in the dairy industry. More research is required regarding sensory properties of the fermented product.

\section{ACKNOWLEDGMENTS}

Research supported by COFECUB (Comité Français d'Études et de Coopération Universitaire avec le Brésil) and CAPES (Coordenação de Aperfeiçoamento de Pessoal de Nível Superior, Brazil).

\section{REFERENCES}

Adamberg K, Kask S, Laht TM and Paalme T (2003). The effect of temperature and pH on the growth of lactic acid bacteria: a pH-auxostat study. Int. J. Food Microbiol. 85: 171-183.

Akerberg C, Hofvendahl K, Zacchib G and Hahn-Hägerdal B (1998). Modeling the influence of pH, temperature, glucose and lactic acid concentrations on the kinetics of lactic acid production by Lactococcus lactis spp. lactis ATCC 19435 in whole wheat flour. Appl. Microbiol. Biotechnol. 49: 682-690.

Almeida KE, Tamime AY and Oliveira MN (2008). Acidification rates of probiotic bacteria in Minas frescal cheese whey. LWT- Food Sci. Technol. 41: 311-316.

Badis A, Guetarni D, Moussa Boudjema B, Henni DE, et al. (2004). Identification and technological properties of lactic acid bacteria isolated from raw goat milk of four Algerian races. Food Microbiol. 21: 579-588.

Berlett BS and Stadtman ER (1997). Protein oxidation in aging, disease, and oxidative stress. J. Biol. Chem. 272: 20313-20316.

Corrieu G, Spinnler H, Picque D, Jomier Y, et al. (1988). Procédé de mise en évidence et de contrôle de l'activité acidifiante d'agents de fermentation dans des bains de fermentation et dispositif pour sa mise en oeuvre. Institut National de la Recherche Agronomique, assignee. French Pat. No. 8814456.

Damin MR, Minowa E, Alcântara MR and Oliveira MN (2008). Effect of cold storage on culture viability and some rheological properties of fermented milk prepared with yogurt and probiotic bacteria. J. Texture Stud. 39: 40-55.

Duwat P, Cesselin B, Sourice S and Gruss A (2000). Lactococcus lactis, a bacterial model for stress responses and survival. Int. J. Food Microbiol. 55: 83-86.

Fridowich I (1998). Oxygen toxicity: a radical explanation. J. Exp. Biol. 201: 1203-1209.

Gadaga TH, Mutukumira AN and Narvhus JA (2001). Growth characteristics of Candida kefyr and two strains of Lactococcus lactis subsp. lactis isolated from Zimbabwean naturally fermented milk. Int. J. Food Microbiol. 70: 11-19.

Grattepanche F, Audet P and Lacroix C (2007). Milk fermentation by functional mixed culture producing nisin $\mathrm{Z}$ and exopolysaccharides in a fresh cheese model. Int. Dairy J. 17: 123-132.

Kristo E, Biliaderis CG and Tzanetakis N (2003). Modelling of rheological, microbiological and acidification properties of a fermented milk product containing a probiotic strain of Lactobacillus paracasei. Int. Dairy J. 13: 517-528.

Miyoshi A, Rochat T, Gratadoux JJ, Le Loir Y, et al. (2003). Oxidative stress in Lactococcus lactis. Genet. Mol. Res. 2: 348359.

Rochat T, Gratadoux JJ, Corthier G, Coqueran B, et al. (2005). Lactococcus lactis SpOx spontaneous mutants: a family of oxidative-stress-resistant dairy strains. Appl. Environ. Microbiol. 71: 2782-2788.

Tamime AY, Robinson RK and Latrille E (2001). Yoghurt and other Fermented Milks. 1st edn. In: Mechanization and Automatization in Dairy Technologies (Tamime AY and Law BA, eds.). Sheffield Academic Press, Reading, 152-203.

Walstra P, Wouters JTM and Geurts TJ (2006). Dairy Science and Technology. CRC Press, New York, 357-397. 